\title{
Learning Competency, Entrepreneurial Orientation Entrepreneurial Innovativeness, and Business Growth: A Study Among Malaysian Chinese Entrepreneurs
}

\author{
Hiew Foo Hiung \\ Sunway University Business School \\ Sunway University, \\ No. 5 Jalan Universiti Bandar Sunway \\ Malaysia. \\ hiewfoohiung@gmail.com
}

Professor Dr. Sulaiman Sajilan

Dean and Professor, Universiti Kuala Lumpur Business

School, Level 8, Bangunan Yayasan Selangor

No.74, Jalan Raja Muda Abdul Aziz, 50300 Kuala Lumpur, Malaysia.

drsulaiman@unikl.edu.my

\author{
Dr. Shehnaz Tehseen \\ Lecturer, Department of Management, \\ Sunway University Business School \\ Sunway University, \\ Malaysia. \\ shehnazt@sunway.edu.my \\ Dr. Ashkan Memari \\ Lecturer, Department of Management, \\ Sunway University Business School \\ Sunway University, \\ Malaysia. \\ ashkanm@sunway.edu.my
}

\begin{abstract}
It has been widely acknowledged that Malaysian Chinese entrepreneurs significantly contribute in the success of SMEs' businesses. This study examined the effect of entrepreneurial innovativeness on the wholesale and retail SMEs' business growth under the moderating impacts of market turbulence among Chinese entrepreneurs. Additionally, learning competency and entrepreneurial orientation were also assessed entrepreneurial innovativeness' antecedents. In addition, Composition Based View (CBV) as well as Strategic Contingency Theory (SCT) were identified as the underpinning theories for this study. Six hypotheses were developed according to the proposed research model and the data were gathered from target respondents using convenience. A total of 110 retail SMEs' owners from Kuala Lumpur as well as Selangor participated in a face-to-face survey procedure. The data were collected at one point of time across the sample population. The findings revealed the positive and significant impacts of learning competency as well as entrepreneurial orientation on the innovativeness. Likewise, based on the findings, market turbulence as a moderator also influenced significantly on business growth. Furthermore, entrepreneurial innovativeness was found as a mediator between learning competency and business growth as well as between entrepreneurial orientation and business growth.
\end{abstract}

Keywords- Learning Competency, Entrepreneurial Orientation, Innovativeness, Market Turbulence, Business Growth.

\section{INTRODUCTION}

According to the Malaysia economic census in 2011, Malaysia's SMEs comprise of 662,939 units of total business establishments, which is equal to $97.3 \%$ [12]. While based on the SME Annual Report 2014/2015, Malaysian SMEs listed a significant growth of $13.6 \%$ in 2014, as well as a raise from $33.5 \%$ to $36 \%$ for SMEs' share to GDP.

Since business growth is the vital aspect of every retail firm, therefore, it is important to determine the factors to achieve growth. Chinese retail firms in Malaysia are facing a significant change which affects the business growth hence there is a need to use innovative approaches towards retail business Pursuit of innovativeness aimed to enhance business growth, however may be affected by market turbulence. The internal factors (learning competency, entrepreneurial orientation) which stimulate firms to generate innovations, to adopt innovations and how they prioritize between the two. 


\section{A. Proposed Theoretical Framework and Development of Hypotheses}

This study is based on integration of two most relevant theories, which including Composition Based View (CBV) and Strategic Contingency Theory (SCT). CBV has been associated with learning competency, entrepreneurial orientation, and innovativeness; while SCT is used to support the moderator which is the environmental turbulence. This study is conducted based on several variables, which are the antecedents, independent variable, moderator and dependent variables. The study has considered learning competency and entrepreneurial orientation as the antecedents of innovativeness. Moreover, innovativeness is the mediator variable in between two predictors and business growth, whereas, business growth is the main dependent variables in this study. Based on CBV by [26], learning competency, entrepreneurial orientation, and entrepreneurial innovativeness are the ordinary type of internal resources for retail SMEs because they are not unique, not rare, as well as can be easily developed without the assistance of core technology. Likewise, the current study regarded that these common internal resources are insufficient to determine the growth of the retail SMEs due to the turbulent business environment that involves strong competition, unpredictable actions of competitors, and fluctuation of customers' demands and preferences. Thus, according to Strategic Contingency Theory (STC) by [18] and [37], internal resources should be matched with external environment because the growth of any business also depends on external business environments particularly market turbulence.

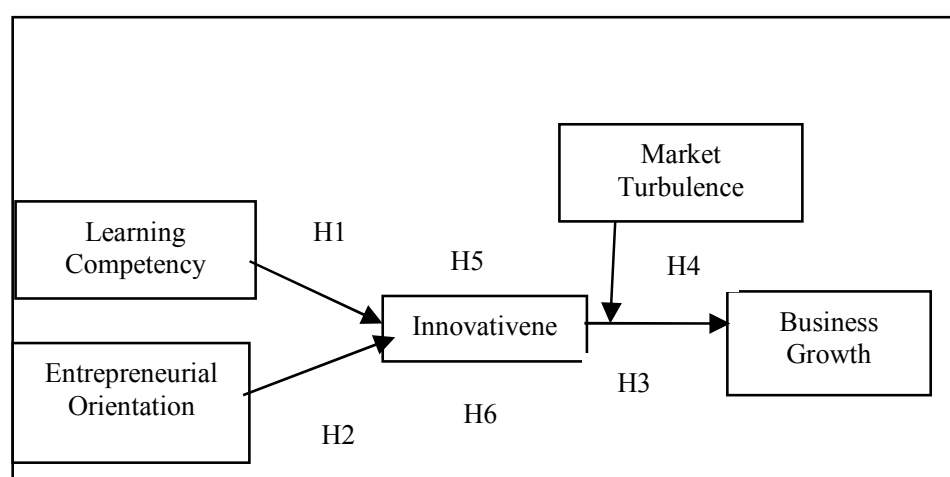

Fig.1 Proposed Model

Figure 1 shows the proposed model that consists of constructs including learning competency, entrepreneurial orientation, innovativeness, market turbulence, and business growth. Based on the review of many relevant studies, several hypotheses are articulated to present the causal links of learning competency, entrepreneurial orientation, innovativeness, market turbulence, and business growth and non-financial performance. The developed hypotheses are described as below:

\section{B. Development of Hypotheses \\ 1) Effect of Learning Competency on Innovativeness.}

The organisational innovativeness links from the basis of knowledge which is possessed by organisation as well as generated by learning competency of the organisation [9, 30]. Organisational learning is regarded as a strategical variable for organisations or firms to create new products and establish new markets to sustain in the extreme competition [6]. Thus, it is important to promote the development of factors which can affect the innovation to achieve competitive advantages over competitors in the industry [27].

The learning competency of organisation determines its new knowledge, creativity, potential to use them, favors of organisational intelligence and background form of orientation to organizational innovation [15]. Thus, learning competency can contribute to the greater innovative orientation as well as activity in the organisation. Thus, hypothesis as below is established in this regard.

H1: Learning competency positively effects the innovativeness.

\section{2) Impact of Entrepreneurial Orientation on} Innovativeness.

An entrepreneurial firm engaged on experimentation which involves innovativeness, risk-taking as well as proactiveness. It is therefore developed as a structure of firm-level entrepreneurship which relates to the term of entrepreneurial orientation once the three elements of Miller's definition is achieved [10, 28]. Thus, EO is considered as a firm-level strategic procedure which reflects on engagement in entrepreneurial actions. The higher tendency to engage in action of entrepreneurship will likely to increase the level of activity, which positively impacts on innovation [38] as well as growth [10]. The hypothesis is formulated as below:

$\mathrm{H} 2$ : Entrepreneurial orientation positively effects the innovativeness.

\section{3) Effect of Innovativeness on Business Growth}

One of the main elements of business growth is innovation [14]. Firms can benefit from temporary monopoly rents by creating new inventions to the market without product imitation and substitution by competitors in the same industry. According to [35], firms are able to maintain their position in generating rent through the continuous flow of innovation. In addition, this will lead to higher sales (i.e., growth) if developments of innovations produce first-mover advantages [38]. Furthermore, the positive effect of innovativeness on business growth has often documented in the context of fast leading firms [5]. Thus, the literature review and justifications lead to the hypothesis as below:

H3: Innovativeness positively effects the business growth. 


\section{4) Moderating Effect of Market Turbulence on Innovativeness and Business Growth Realtionship}

In the business context, innovation and the innovativeness of organisation determines the business growth. A firm that constantly creates and adapts innovation can gain their position in the market in turn promote business growth through the increase of sales volume [38]. Innovativeness is related to business growth based on many studies [5]. However, this relationship should consider the external factors such as environmental turbulence, which is also known as the dynamic environment where continuous and rapid change in product, technology and competition level. The environmental turbulent indicates the turbulence or uncertainty of markets as well as level of competitions among existing firms [22]. Market turbulence is illustrated because of unpredictable customers' needs, competitive intensity within firms and unpredictable competitors' action are the primary uncertainties in wholesale as well as retail SMEs business environments. Due to the rapid change and rising of complexity of customers' need, innovative practices are essential to minimize such challenges which creates competitive edge over other firms [24]. In addition, [8] believed that those innovative firms attain higher success and excellent performance outcomes in a high market turbulence context. Therefore, following hypothesis is developed:

H4: The moderating effect of market turbulence is positive for innovativeness and business growth relationship.

\section{METHODOLOGY}

\section{A. Data Collection Methods and Sampling Design}

This study used a standard survey approach because it constituted quantitative study. The data was collected from Malaysian Chinese retailers who were dealing in retail businesses located at the states of Selangor and Kuala Lumpur. Target respondents were approached using convenience sampling. All the constructs' measures were adopted from existing studies. For instance, 4 items were used to measure business growth, learning competency, and 3 items to measure market turbulence were taken from [1]. To measure entrepreneurial innovativeness, 4 items were also adopted from [21] and [23]. Whereas, 6 items were used from [28] to measure entrepreneurial orientation. Pretesting was conducted among 7 experts and then the items were modified based on their suggestions.

Data were collected by researcher from the target respondents from Selangor as well as Kuala Lumpur who belonged to retail industry. Before collecting data from respondents, the respondents' educational background was considered to ensure their understanding of the questionnaire. Thus, face to face meeting method is considered as effective in getting responses through standardised questionnaire survey. It assured that respondents completely answered to the questionnaire with fully understand the content.

$\mathrm{G}^{*}$ power has been commonly used in behavioural research which was designed by [13]. With 2 predictors, to achieve power of 0.80 , it was essential to have the least sample size of 68 for our framework [17]. Since, the data were collected from 110 respondents that was exceeded the minimum sample size requirement.

\section{B. Data Analysis Techniques \\ 1) Statistical Remedies to Assess CMV}

Two statistical techniques were used to access issue of CMV namely [25] and Correlation Matrix Approach by [3]. By using [25] method, the correlation among main constructs and irrelevant variable found less than 0.3. Likewise, based on Correlation Matrix Approach, the correlation among the key constructs were found below 0.9 as well. Both approaches indicated the lack of CMV in this study.

\section{2) Demographic Profile of Respondents}

A total of 110 entrepreneurs from the Malaysian wholesale and retail firms participated in survey. All survey respondents are Chinese entrepreneurs as targeted of the survey criteria. The majority of respondents were above age of 30 years. Overall, 80 respondents $(72.7 \%)$ of the survey were male whereas $30(27.3 \%)$ of them were female. $41(37.3 \%)$ of them possessed diploma, while 40 respondents $(36.4 \%)$ only completed certificate level of education, 24 respondents $(21.8 \%)$ were having the bachelor degree and $5(4.5 \%)$ of them possessed the master degree. $50 \%$ firms belonged to Selangor and $50 \%$ to Kuala Lumpur. $8(7.3 \%)$ of the total firms were involved in pharmaceutical goods, $17(15.5 \%)$ were dealing in textile and clothing, $9(8.2 \%)$ in leather and footwear goods, $8(7.3 \%)$ in household appliances and equipment, $4(3.6 \%)$ in recreational goods, $9(8.2 \%)$ in spa, salon, and boutique, $6(5.5 \%)$ in gifts and crafts, $1(0.9 \%)$ in watches, $2(1.8 \%)$ in perfumes, $7(6.4 \%)$ in furniture, $4(3.6 \%)$ in toys, $1(0.9 \%)$ in books, $3(2.7 \%)$ in interior decorators, 1 $(0.9 \%)$ in towel and bed sheets, $2(1.8 \%)$ in gold and diamond, and $28(25.5 \%)$ were dealing in other business formats

\section{3) Inferential Data Analysis}

The measurement model analysis involves the assessment of the relationships among the indicators and their corresponding constructs $[16,34]$. The measurement model assessment consists of analysis of validity as well as reliability of items and constructs. Table 1 shows that all the reliabilities' values were higher than the standard minimum value of 0.70 .

TABLE 1

ASSESSMENT OF RELIABILITIES AND AVE 


\begin{tabular}{|c|c|c|c|c|c|c|}
\hline Constructs & & & $\begin{array}{l}\text { Composite } \\
\text { Reliability }\end{array}$ & rho_A & $\begin{array}{c}\text { Cronbach's } \\
\text { Alpha }\end{array}$ & $\begin{array}{c}\text { Average } \\
\text { Variance } \\
\text { Extracted } \\
\text { (AVE) }\end{array}$ \\
\hline \multirow[t]{4}{*}{ BG } & BG1 & 0.799 & \multirow[t]{4}{*}{0.848} & \multirow[t]{4}{*}{0.779} & \multirow[t]{4}{*}{0.762} & \multirow[t]{4}{*}{0.583} \\
\hline & BG2 & 0.722 & & & & \\
\hline & BG3 & 0.714 & & & & \\
\hline & BG4 & 0.813 & & & & \\
\hline \multirow[t]{6}{*}{ EO } & EO1 & 0.81 & \multirow[t]{6}{*}{0.903} & \multirow[t]{6}{*}{0.884} & \multirow[t]{6}{*}{0.871} & \multirow[t]{6}{*}{0.608} \\
\hline & EO2 & 0.826 & & & & \\
\hline & EO3 & 0.664 & & & & \\
\hline & EO4 & 0.838 & & & & \\
\hline & EO5 & 0.781 & & & & \\
\hline & EO6 & 0.747 & & & & \\
\hline \multirow[t]{4}{*}{ INN } & INN1 & 0.747 & \multirow[t]{4}{*}{0.904} & \multirow[t]{4}{*}{0.869} & \multirow[t]{4}{*}{0.857} & \multirow[t]{4}{*}{0.702} \\
\hline & INN2 & 0.895 & & & & \\
\hline & INN3 & 0.884 & & & & \\
\hline & INN4 & 0.816 & & & & \\
\hline \multirow[t]{4}{*}{ LC } & LC1 & 0.924 & \multirow[t]{4}{*}{0.935} & \multirow[t]{4}{*}{0.92} & \multirow[t]{4}{*}{0.907} & \multirow[t]{4}{*}{0.783} \\
\hline & LC2 & 0.864 & & & & \\
\hline & LC3 & 0.858 & & & & \\
\hline & LC4 & 0.891 & & & & \\
\hline \multirow[t]{3}{*}{ MT } & MT1 & 0.725 & \multirow[t]{3}{*}{0.792} & \multirow[t]{3}{*}{0.632} & \multirow[t]{3}{*}{0.624} & \multirow[t]{3}{*}{0.56} \\
\hline & MT2 & 0.710 & & & & \\
\hline & MT3 & 0.805 & & & & \\
\hline
\end{tabular}

Furthermore, the assessment of HTMT proposed by [19] was done to test discriminant validity as well. Table 2 reveals that discriminant validity was established because no value was found above 90 and with interval value of 1 [19].

TABLE 2

HETEROTRAIT-MONOTRAIT RATIO (HTMT)

\begin{tabular}{|c|c|c|c|c|c|}
\hline & BG & EO & INN & LC & MT \\
\hline BG & & & & & \\
& & & & & \\
\hline EO & 0.634 & & & & \\
& $(0.451$, & & & & \\
& $0.758)$ & & & & \\
& & & & & \\
\hline INN & 0.404 & 0.694 & & & \\
& $(0.211$, & $(0.506$, & & & \\
& $0.623)$ & $0.817)$ & & & \\
& & & & & \\
\hline LC & 0.333 & 0.527 & 0.614 & & \\
& $(0.165$, & $(0.341$, & $(0.432$, & & \\
& $0.506)$ & $0.674)$ & $0.735)$ & & \\
& & & & & \\
\hline MT & 0.541 & 0.451 & 0.407 & 0.390 & \\
& $(0.331$, & $(0.241$, & $(0.208$, & $(0.222$, & \\
& $0.696)$ & $0.651)$ & $0.546)$ & $0.569)$ & \\
& & & & \\
\hline
\end{tabular}

After conducting the measurement model analysis, the analysis of structural model was done using PLS-SEM. Results reveal that VIF values of all constructs were lower than 0.50 , which indicates that multicollinearity issues did not exist in this model. The hypotheses' results are shown in Table 3.
TABLE 3

TESTING OF HYPOTHESIS

\begin{tabular}{|c|c|c|c|c|c|}
\hline & $\begin{array}{l}\text { Original } \\
\text { Sample } \\
\text { (O) }\end{array}$ & $\begin{array}{c}\text { Sample } \\
\text { Mean } \\
\text { (M) }\end{array}$ & $\begin{array}{c}\text { Standar } \\
\text { d } \\
\text { Deviatio } \\
\text { n } \\
\text { (STDEV } \\
\text { ) }\end{array}$ & $\begin{array}{c}T \\
\text { Statistics } \\
(\mid \mathbf{O} / \mathbf{S T D E} \\
\mathrm{V} \mid)\end{array}$ & Decision \\
\hline H1: LC -> INN & 0.341 & 0.335 & 0.081 & $* * * 4.208$ & Supported \\
\hline H2: EO -> INN & 0.448 & 0.46 & 0.086 & $* * * 5.218$ & Supported \\
\hline H3: INN -> BG & 0.242 & 0.264 & 0.094 & $* * * 2.571$ & Supported \\
\hline $\begin{array}{l}\text { H4: INN*MT }-> \\
\text { BG }\end{array}$ & 0.2 & 0.25 & 0.107 & $* 1.872$ & Supported \\
\hline $\begin{array}{l}\text { H5: LC -> INN -> } \\
\text { BG }\end{array}$ & 0.079 & 0.075 & 0.034 & 2.296 & Supported \\
\hline $\begin{array}{l}\text { H6: EO -> INN - } \\
>\text { BG }\end{array}$ & 0.103 & 0.11 & 0.053 & 1.943 & Supported \\
\hline
\end{tabular}

Note: $t$ values with $*$ indicates significance level of $10 \%), * * \& * * *$ indicate significance level of $5 \%$ and $1 \%$ respectively.

Table 3 reveals the direct influence of LC on INN. According to the result shown, $\mathrm{H} 1$ is accepted because t-value is significant $(\beta=0.341, \mathrm{t}=4.208)$. This indicates that there is a positive impact of LC on INN which is also significant. The direct influence of EO on INN is also revealed. Thus, H2 is accepted because $t$-value is significant $(\beta=0.448, t=5.218)$. This indicates that the positive impact of INN on BG which is significant. Likewise, $\mathrm{H} 3$ is also accepted because t-value is significant $(\beta=0.242, \mathrm{t}=2.571)$. Findings also show that $\mathrm{H} 4$ is supported because the t-value is significant and the interaction term's impact is positive $(\beta=0.2, \mathrm{t}=1.872)$. Based on this result MT positively moderates the impact of INN on $\mathrm{BG}$ and its influence is significant. Furthermore, indirect effects were also found for H5 $(\beta=0.079)$, and H6 $(\beta=0.103)$ with significant t-values of 2.296 and 1.943 respectively.

Furthermore, $\mathrm{R}^{2}$ values of $\mathrm{BG}$ and INN were 0.26 and 0.459 respectively which are high according to [7]. The $\mathrm{f}^{2}$ effect sizes of INN and INN*MT were 0.072 and 0.058 respectively for $\mathrm{BG}$ considered as small [7]. On the other hand, $\mathrm{f}^{2}$ effect sizes of EO and LC were 0.289 and 0.168 for INN respectively that are considered as medium (Cohen, 1988). The $\mathrm{Q}^{2}$ values more than 0 signify the predictive relevance for endogenous construct. Since all the values of BG $(0.121)$ and INN (0.297) are above 0, thus, these values show the medium predictive relevance of predictors for the endogenous constructs. 


\section{DISCUSSION AND CONCLUSION}

The findings indicate that high learning competency would elevate a firm's innovativeness towards Malaysia businesses in the future. This result seems consistent with [15] finding that learning competency has significant impact towards innovativeness. Furthermore, the possible reason for explaining this finding is that organisation innovation is contingent on organisational learning [9]. Therefore, learning competency is important for firms to innovate continuously for continuous survival in the intense competition. As the results, learning competency has a positive relationship with innovativeness. Findings show positive influence of entrepreneurial orientation on innovativeness. This result seems consistent with [10] and [38] findings regarding same effect. In addition, the possible reason for explaining this finding is that through entrepreneurial orientation, there is higher tendency increase the engagement of entrepreneurship action as well as activity level, whereby it brings in more innovation to an organisation. The result also indicates that high level of innovativeness would elevate the business growth towards. This result seems consistent with [38] findings that innovativeness has significant impact on business growth. This is because the firms with stronger innovation tend to better deal their uncertain environments and easily acquire critical capabilities to increase firms' performance, as well as to strengthen their sustainable competitive advantage [2]. Thus, innovativeness positively influences the business growth.

Additionally, it was found that innovativeness and business growth relationship could be enhanced only when the market turbulence is higher as compared to when it is lower. Some other studies have also found similar type of relationship under various contexts [8]. One of the possible reasons of this finding is that innovation is regarded as the main key driver for a long period of business success specifically in the dynamic markets [11]. Innovation assists the firms to deal with turbulent business environment [29]. Due to the rapid changes of customers' preferences and competitors' action in such competitive business environments, the firms tend to be more pressured and use innovative practices to respond towards such threats [32].

Furthermore, the mediating influence of entrepreneurial innovativeness for learning competency and business growth relationships and for entrepreneurial orientation and business growth relationships were in line with some other researchers who also found these impacts [36, 31, 20,2].

\section{LIMIITATIONS AND FUTURE RECOMMENDATIONS}

The convenience sampling is the first limitation of this study due to which the findings cannot be generalised over entire population of Malaysian Chinese retailers. The second limitation of this study is that it was conducted only among Malaysian Chinese retailers and it did not consider the other two ethnic groups of entrepreneurs namely Malays and
Indians. Thirdly, since the data were collected from same type of respondents, however, the statistical remedies were not applied to correct the CMV. Lastly, since this study's scope was only limited to Malaysian Chinese entrepreneurs, thus, this study's findings cannot be generalized among other developing countries' retailers. Therefore, to overcome these limitations, the future researchers should strive to use random sampling across entire Malaysian retail businesses to generalize the findings. Moreover, the future research can emphasize on the comparative study among Malaysian Chinese, Malay, and Malaysian Indian entrepreneurs regarding the effects of different capabilities on business growth under the moderating role of market turbulence. Further research can test this study's conceptual model among other developing countries' retailers.

\section{REFERENCES}

[1] Ahmad, N. H., "A Cross Cultural Study of Entrepreneurial Competencies and Entrepreneurial Success in SMEs in Australia and Malaysia" (doctoral dissertation), The University of Adelaide, Adelaide, South Australia, 2007.

[2] Ali, M., and Park, K., "The mediating role of an innovative culture in the relationship between absorptive capacity and technical and non-technical innovation", Journal of Business Research, vol.69, no.5, pp.1669-1675, 2016.

[3] Bagozzi, R. P., Yi, Y. and Phillips, L. W. “Assessing Construct Validity in Organizational Research", Administrative Science Quarterly, pp. 421458, 1991.

[4] Bommer, M. and Jalajas, D. S., "Innovation Sources of Large and Small Technology-Based Firms", IEEE Transactions on Engineering Management, vol.51, no.1, pp. 13-18, 2004.

[5] Brüderl, J., and Preisendörfer, P., "Fast-growing businesses: empirical evidence from a German study", International journal of sociology, vol.30, no.3, pp.45-70, 2000.

[6] Cefis, E., "A matter of life and death: innovation and firm survival", Industrial And Corporate Change, vol.14, no.6, pp.1167-1192, 2005, doi: 10.1093/icc/dth081.

[7] Cohen, J, "Statistical Power Analysis for the Behavioural Sciences", Hillsdale, NJ: Lawrence Earlbaum Associates, 1988.

[8] Chandler, G. N., Keller, C. and Lyon, D. W., "Unraveling the Determinants and Consequences of an Innovation-Supportive Organizational Culture", Entrepreneurship: Theory and Practise, vol.25, no.1, pp.59-59, 2000.

[9] Cohen, W., and Levinthal, D., “Absorptive Capacity: A New Perspective on Learning and Innovation", AdministrativeiScience Quarterly, vol.35, no.1, pp.128, 1990, doi: 10.2307/2393553.

[10] Covin, J. G. and Slevin, D. P., "Strategic Management of Small Firms in Hostile and Benign Environments", Strategic Management Journal, vol.10, no.1, pp.75-87, 1989.

[11] Damanpour, F. and Gopalakrishnan, S., "The Dynamics of the Adoption of Product and Process Innovations in Organisations", Journal of Management Studies, vol.38, no.1, pp.45-65, 2001.

[12] Department of Statistic Malaysia, "Small and medium enterprises 20052013", 2017.

[13] Erdfelder, E., Faul, F. and Buchner, A., "G Power: A General Power Analysis Program", Behavior Research Methods, Instruments \& Computers, vol.28, no.1, pp.1-11, 1996. 
[14] Garnsey, E., Stam, E. and Heffernan, P., "New Firm Growth: Exploring Processes and Paths", Industry and Innovation, vol.13, no.1, pp.1-20, 2006.

[15] Garcia-Morales, V. J., Lloréns-Montes, F. J., and Verdu-Jover, A. J. , "Influence of personal mastery on organizational performance through organizational learning and innovation in large firms and SMEs", Technovation, vol.27, no.9, pp.547-568, 2007.

[16] Hair, J. F., Hult, G. T. M., Ringle, C. and Sarstedt, M., “A Primer on Partial Least Squares Structural Equation Modeling (PLS-SEM)”, 1st ed, Thousand Oaks, CA: Sage, 2014.

[17] Hair, J. F., Hult, G. T. M., Ringle, C. M. and Sarstedt, M., "A Primer on Partial Least Squares Structural Equation Modeling (PLS-SEM)”, 2nd ed, Thousand Oaks, CA: Sage., 2017.

[18] Hofer, C. W., "Toward a Contingency Theory of Business Strategy", Academy of Management Journal, vol.18, no.4, pp.784-810, 1975.

[19] Henseler, J., Ringle, C. M. and Sarstedt, M., “A New Criterion for Assessing Discriminant Validity in Variance-Based Structural Equation Modeling”, Journal of the Academy of Marketing Science, vol.43, no.1, pp.115-135, 2015.

[20] Ibeku, S., "Organisational Learning, Innovation and Performance of Technology Start-Ups In Lagos, Nigeria", International Journal of Innovation Management, vol.22, no.03, pp.1850023, 2018.

[21] Idris, A., "An Inter-Ethnic Study of Gender Differentiation and Innovativeness among Women Entrepreneurs in Malaysia", South African Journal of Business Management, vol.41, no.4, pp.35-46, 2010.

[22] Jaworski, B. J. and Kohli, A. K., "Market Orientation: Antecedents and Consequences", The Journal of Marketing, vol.57, no.3, pp.53-70, 1993.

[23] Juri, K. A. M., "The Relationship between Cultural Values and Innovativeness: A Study of Malay and Chinese Entrepreneurs in Malaysia”, master's thesis, University of Malaya, Malaysia, 2009.

[24] Jimenez-Jimenez, D., Sanz Valle, R. and Hernandez-Espallardo, M., "Fostering Innovation: The Role of Market Orientation and Organisational Learning", European Journal of Innovation Management, vol.11, no.3, pp.389-412, 2008.

[25] Lindell, M. K. and Whitney, D. J., "Accounting for Common Method Variance in Cross-Sectional Research Designs. Journal of Applied Psychology, vol.86, no.1, pp.114-121, 2001.

[26] Luo, Y., and Child, J., "A composition-based view of firm growth", Management and Organization Review, vol.11, no.3, pp.379-411, 2015.

[27] Lloréns Montes, F., Ruiz Moreno, A., and García Morales, V., "Influence of support leadership and teamwork cohesion on organizational learning, innovation and performance: an empirical examination", Technovation, vol.25, no.10, pp.1159-1172, 2005, doi: 10.1016/j.technovation.2004.05.002.

[28] Miller, D. and Friesen, P. H., "Strategy-Making and Environment: The Third Link", Strategic Management Journal, vol. 4, no.3, pp. 221-235, 1983.

[29] Naranjo-Valencia., Jiménez-Jiménez, D. and Sanz-Valle, R., "Studying the Links between Organisational Culture, Innovation and Performance in Spanish Companies", Revista Latinoamericana De Psicología, vol.48, no.1, pp.30-41, 2016.

[30] Nonaka, I. and Takeuchi, H., "The Knowledge Creation Company: How Japanese Companies Create the Dynamics of Innovation", Oxford University Press, New York, USA, pp.304, 1995.

[31] Obeidat, B. Y., "The effect of strategic orientation on organizational performance: The mediating role of innovation", International Journal of Communications, Network and System Sciences, vol.9, no.11, pp.478, 2016.

[32] Prajogo, D. I., "The Strategic Fit between Innovation Strategies and Business Environment in Delivering Business Performance", International Journal of Production Economics, vol.171, pp.241-249, 2016.
[33] Preacher, K. J., and Hayes, A. F., "Assessing mediation in communication research", The Sage sourcebook of advanced data analysis methods for communication research, 13-54, 2008.

[34] Ramayah, T., Cheah, J., Chuah, F., Ting, H., Memon, M.A., "Partial Least Squares Structural Equation Modelling (PLS-SEM) using SMARTPLS 3.0: An Updated and Practical Guide to Statistical Analysis", $2^{\text {nd }}$ edt, Pearson: Malaysia, 2018.

[35] Rosenbusch, N., Brinckmann, J., and Bausch, A., "Is innovation always beneficial? A meta-analysis of the relationship between innovation and performance in SMEs", Journal of business Venturing, vol.26, no.4, pp.441-457, 2011.

[36] Sajilan, S., and Tehseen, S., "Network competence and firm performance: The mediating role of entrepreneurial innovativeness among Malaysian Chinese entrepreneurs of wholesale businesses", Asian Academy of Management Journal, vol.24, Supp. 1, pp.187-201, 2019.

[37] Steiner, G. A., "Contingency Theories of Strategy and Strategic Management", Strategic Management: A New View of Business Policy and Planning, Little, Brown, Boston, MA, pp.405-416, 1979.

[38] Zahra, S. A. and Covin, J. G., "Contextual Influences on the Corporate Entrepreneurship-Performance Relationship: A Longitudinal Analysis”, Journal of Business Venturing, vol.10, no.1, pp.43-58, 1995. 